\title{
I CAESAREAN BIRTH IN MEDICAL THOUGHT
}

\begin{abstract}
Caesarean birth had a place in medieval culture before it began to interest learned physicians. Medieval scholars interested in the ancient Romans and in the intricate problems of etymology occupied themselves with the question of the origin of Julius Caesar's name and whether he was born by Caesarean section; in addition, legends and miracles concerning Caesarean birth became part of the popular imagination. ${ }^{1}$ Since the medieval ideas on Caesarean birth inherited from antiquity came from nonmedical sources, the operation did not appear in the canon of medical texts used by medieval physicians. It was not until the early fourteenth century that remarks on postmortem Caesarean sections began to emerge in medical treatises.
\end{abstract}

\section{Pregnancy, Childbirth, and Obstetrics}

She twisted and turned and writhed, this way, that way, to and fro, and continued so until, with much labour she bore a little son. But see, it lived, and she lay dead. ${ }^{2}$

Madame saincte Marguerite, digne vierge de Dieu eslite, qui Dieu servis dés ta jeunesse, plaine de grace et de sagesse, qui pour l'amour de Nostre Sire souffris maint grant et grief martire, qui le dragon parmi fendis 


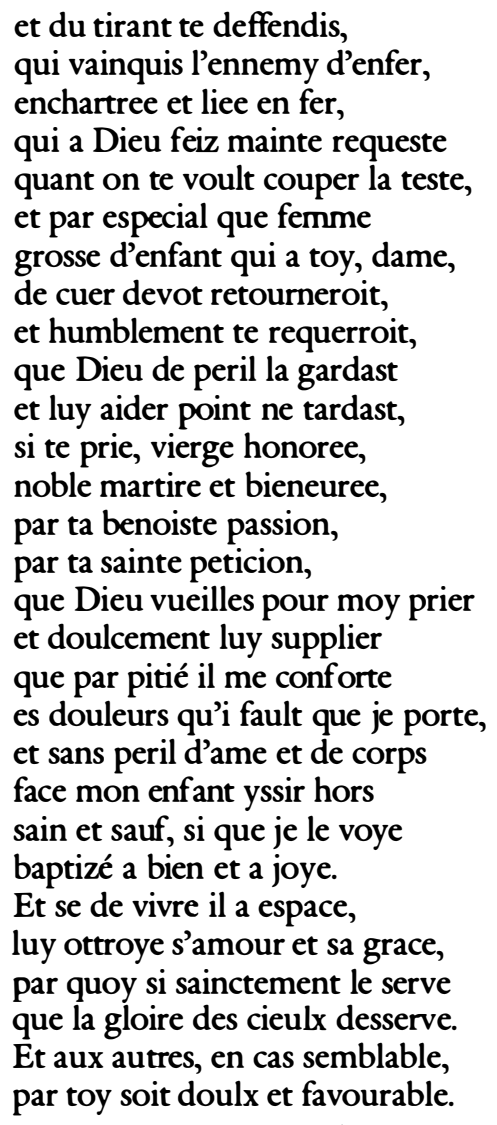

AMEN

([Medieval women in the throes of childbirth prayed to Saint Margaret:] Madame, Saint Margaret, / worthy virgin, elected by God, / who served God from her youth, / full of grace and wisdom, / who for the love of Our Lord / suffered such a great and painful martyrdom, / who cut the dragon in half / and defended yourself against the tyrant, / who vanquished the enemy from hell / who was imprisoned and bound with iron, / who made many a request to God / when they wanted to cut off your head, / and especially when a woman / big with child who turns her devout heart towards you / and humbly begs you / that God may save her from peril, / and may not delay His help to her, / this is when I pray to you honored virgin / noble and blessed martyr / through your blessed passion, / through your saintly petition / may you pray to God for me / and sweetly ask Him / that He may comfort me through His pity / in the pain which I have to undergo / and that $\mathrm{He}$ - without danger to soul or body - make my child come out / safe and sound, so that I can see him / baptized joyously. / And 
so that he has room to live / may He give him His love and His Grace / for which he will serve Him in such a saintly way / that he may deserve the glory of the heavens. I And to others, in similar cases, through you, be sweet and favorable. Amen.) ${ }^{3}$

A fifteen-year old woman gives birth to a dead baby girl. Despite the devoted help of her chambermaid and a neighbor, after the birth she loses all sensation in her body below the waist. Burning candles and glowing coals are applied to her feet to test the insensitivity of her body-to no avail. For one and a half years no change in her condition occurs. It is only when she hears of the miracles that are happening at the tomb of Saint Louis (whose bones had been translated on that very day [May 22, I28I] to Saint Denis) that she envisions a possible cure for her ailment. She promises to attend mass every year at his anniversary, not to work on that day, and to become his pilgrim. After she touches the tomb and then the sick parts of her body, she lies down beside the tomb. Nine days later after having performed this ritual daily she feels how the bones in her body start banging together and on the tenth day she regains feeling in the lower part of her body. At the inquiry during Saint Louis's canonization trial her case is examined and witnesses state that she is still healthy (May 1282).

The first example above is Gottfried von Strassburg's early thirteenthcentury description of Tristan's birth. Blancheflor, Tristan's mother, weakened through grief over the recent slaying of her husband, Riwalin, dies while giving birth. This scene undoubtedly reproduces many a medieval birth. Although medieval midwives were aware that emotional stress could result in difficult labor, they had few resources at their disposal that would allow them to prevent the tragic results of such complications.

The second example evokes Saint Margaret. Her story tells how she refused the Roman prefect Olibrius and rather than give up her virginity submitted to hideous tortures. She was then imprisoned and attacked in her prison by a terrifying dragon. When the monster did not manage to devour her, Olibrius finally had her burned with flaming torches and submerged in tubs of water. But she remained unharmed, and the crowd watching her began to be converted. Olibrius then decided to have her beheaded, and a moment before her death she prayed to God not only for herself and her executioners but also for any woman in labor: if the 
woman addressed herself to Saint Margaret for help the birth would have a happy outcome. A voice from heaven promised Margaret that her prayers would be fulfilled, and she went to her death reassured.

Saint Margaret's story was extraordinarily popular in the Middle Ages (it was included in Jacobus of Voragine's Golden Legend), but it is not obvious at first sight which elements in her life predestined her to become the patroness of women in labor. The mixture of ideals of virginity and extreme violence in her story parallels that in the lives of many other virgin martyrs who were raped, mutilated, or forced to enter bordellos before their execution. What distinguishes Saint Margaret's story is the presence and function of the dragon. In different versions of the legend Saint Margaret either avoids being swallowed by the dragon or emerges unharmed from its belly. Given the sexual connotations of the dragonthe Antichrist is often called a lascivious dragon and seducer, for example-and the beliefs that the dragon-viper gives birth by splitting open (the violent and deadly consequences of sexual activity, as Rabanus Maurus pointed out), ${ }^{4}$ Saint Margaret's martyrdom evokes both sexual violence and the pains of childbirth, and it is perhaps for this reason that she offered a prayer for women in labor before her death. Birth, in an age before systematized contraception, was the natural consequence of sexual relations and, for some women at least, must have seemed to be a punishment for the pleasure they experienced during conception. ${ }^{5}$ The violence connected with Saint Margaret's death must have recalled, for many medieval women, the violence they had experienced, either themselves or as witnesses, during childbirth.

The idealization of virginity and the consequent rejection of sexual pleasure, so prevalent in medieval art and theological writings, have their roots in antiquity. Philo of Alexandria (first century A.D.) exalted virginity as a way for women to approach the male level of rationality. ${ }^{6} \mathrm{~A}$ few centuries later, Saint Jerome (340-420) confirmed this idea when he wrote that "as long as woman is for birth and children, she is different from man as body is from soul. But if she wishes to serve Christ more than the world, she will cease to be a woman and will be called a man."7 And almost eleven centuries after Jerome, when the chancellor of the University of Paris wanted to bestow praise on Christine de Pizan he called her "distinguished woman, manly female" (insignis femina, virilis femina). 8

It would be simplistic to see only male oppression and arrogance in this type of statement. As Margaret Miles states with regard to the depiction 
of women in fourteenth-century Tuscan painting: "The idealization of the virginal woman . . . may have symbolized to medieval women freedom from the burden of frequent childbearing and nursing in an age in which these natural processes were highly dangerous." Idealizing virginity may thus have helped women to master the "brutish" aspect of their biologically determined lives. 9

We can now understand better why the Virgin Mary and Saint Margaret were invoked during childbirth. One gave birth without encountering any of the physical suffering related to it; the other sacrificed her life for her virginity but before her death had to undergo torments not unlike those experienced during childbirth. Through her ability to sympathize with tormented women she became their ideal intercessor.

The third example, the case history of a young medieval woman, is the third miracle in the collection of the Miracles de Saint Louis, by Guillaume de Saint-Pathus. It dramatizes the aftermath of a dead birth as a precarious condition for a woman. The symptoms, a type of paralysis (possibly of hysterical origin) resulting in a partial depersonalization, help the woman deny the existence of that part of her body connected with sex and reproduction. It is remarkable that neither the account of the cure nor the final testimony a year later even mentions the possibility of her having more children; nor does the husband appear. This absence is very telling for, as we will see later, medieval birth was entirely in the hands of women. The young woman's symptoms vanished, but the underlying causes - sexuality represented by the absent husband who could have caused another birth-continue to be denied and passed over in silence.

From these three examples medieval birth emerges with all its frightening and often fatal consequences. Where could medieval women find help and comfort in their trials? Before turning to some concrete examples let us briefly examine attitudes toward pregnancy and childhood (necessarily related to those toward motherhood) and what we can know about them in the Middle Ages in order to understand the feelings with which pregnant women and midwives approached the critical moment of childbirth.

Only one passage from the New Testament puts some value on childbearing: "Yet woman will be saved through bearing children, if she continues in faith and love and holiness, with modesty" (I Tim. 2:I5). We should not forget the context of this passage, however, which emphasizes women's duty to be submissive to men, their guilt as descendants of Eve, as well as the interdiction "I permit no woman to teach" (verse 12). Procreation here is seen as a way of salvation, albeit an inferior one. Even 
the command of Genesis "Be fruitful and multiply" was not generally interpreted, in the medieval period, as expressing a positive attitude toward childbirth. Not bodily reproduction but spiritual advancement was the real meaning of this command, according to Saint Thomas Aquinas (1225-74). ${ }^{10}$ In general, the church's attitude toward marriage, sexuality, and pregnancy was negative. ${ }^{11}$ There were some notable exceptions, such as Duns Scotus, who seems to have favored "limitless procreation" in order to restore the city of supernatural citizens in human nature. ${ }^{12}$ But even here children are seen in a spiritual context and not as a value in themselves.

The teachings of the church do not always directly reflect contemporary reality, of course. It would be absurd to say that in the Middle Ages no one enjoyed sex and that parents did not want and love their children. Nevertheless, church teachings posit an ideal that Christians are urged to pursue. And, as Vern Bullough points out, "Church sexual ideals remained much the same at the end of the Middle Ages as they were at the beginning. Although ... Church officials dealt with the world as they found it, the ascetic ideal still dominated, and at best, sexual activity was only to be tolerated providing it resulted in procreation." 13 Although childlessness may have serious consequences for noble families, such as disputes over inheritance and succession rights, ${ }^{14}$ the general spiritual climate of the age did not favor ideas on childbearing as an important social function. In the hierarchy of medieval values, then, procreation and sex ranked extremely low. Thus, even outside of clerical writings, it is hard to come by positive remarks-or any definite remarks, for that matter-on medieval women as mothers.

Whereas many texts, legal and canonical as well as literary, discuss women's rights and duties as wives, they strangely neglect women's role as mothers. ${ }^{15}$ Historians of the family have found several explanations for this scarcity of evidence. According to Philippe Ariès, children had no special place in medieval society. ${ }^{16}$ Emotional attachments to children were not encouraged because of the high infant mortality; even Montaigne, in the sixteenth century, acknowledged that he lost "two or three" children in their infancy-not without regret, it is true, but not with too much fascherie (worry) either. ${ }^{17}$

One of the few literary texts that deal with childbirth is the fifteenthcentury misogynistic treatise Les quinze joies de mariage. The eighth "joy" of marriage is that of childbirth: it gives a woman the opportunity to play sick and to assemble all her gossiping companions (commeres) in the 
house who have nothing better to do than squander the poor husband's belongings. ${ }^{18}$ The situation caricatured here reflects contemporary customs surrounding childbirth. Adrian Wilson has analyzed the importance of this ritual in anthropological terms. The sequence of separation, transition, and reincorporation (represented by the rite of churching) "conforms closely to the classical description of 'rites of passage' developed by Amold van Gennep."19 The "gossips," or "god-siblings," are an important part of the ritual: they prepare the lying-in room, provide nourishment for the attendants, and assure the sequestration of the mother. Les quinze joies provides a different and bitter view of this almost sacred ritual.

According to Ariès, the family as such (as opposed to the concept of lineage) had no emotional reality and consequently did not inspire poets and artists. ${ }^{20}$ This view has been challenged recently in the work of Weinstein and Bell, who argue for "a close-knit, affective family, in which children were caringly treated on their own terms while being prepared for adulthood."21 Weinstein and Bell, of course, deal with the childhood of saints whose families are depicted mostly in the vitae of these saints or in documents related to their canonization. The circumstances of these lives were extraordinary, and it was one of the goals of hagiography to emphasize this extraordinariness. Authors of vitae, even more than those of other medieval narrative genres, worked with topoi of which "the saint's family and his or her relationship to it" was certainly an important one. But there is a great variety in the families' reactions to their children's budding sainthood, and while these scenes are probably not a wholly realistic reflection of medieval family life, they nevertheless allow for some rare glimpses into the relationships between parents and children. Here, women as mothers, caring yet often skeptical when faced with their children's frequently peculiar behavior, make some of their rare and moving appearances in medieval texts.

Many medieval mothers were, like mothers at all periods in history, negligent in the care of their children. Accidental deaths of infants must have been quite common, as one can gather from a canon of the Council of Canterbury (1236) that urges priests to exhort mothers (every single Sunday) not to sleep in the same bed with their infants because they might accidentally smother them; also, infants were not to be left near fire or water without a guardian. ${ }^{22}$ Accidents like these are described in miracle collections such as the Miracles de Saint Louis. The first miracle, for example, tells of a three-and-a-half-year-old girl who, while playing at 
a stream, dips her little bucket too far into the water. She loses her balance, falls into the stream, and is thought to have drowned. Friends of the parents retrieve the dead girl and try to revive her. When all their efforts fail, the parents invoke the aid of Saint Louis by promising him the weight of the girl in rye. At the end of the day, the little girl miraculously returns to life.

Miracle collections are a promising and as yet virtually untapped source of information on family relationships and attitudes toward children. In addition to the story just mentioned, there are many moving examples of parents who go to great lengths to procure help for their sick children. Mothers, fathers, and other family members take turns in spending time with the sick child, going through the rituals at Saint Louis's tomb but constantly worrying about the children they left at home. How realistic are these scenes? In a sense, the personnel for these testimonies is preselected: the parents in these accounts are by definition "good parents" because they took extraordinary trouble in seeking help for their children, however negligent they may have been earlier. Good parents and loving families clearly existed, but they were not a topic chosen by many medieval writers.

Aside from hagiography and miracle collections the literature of the time gives almost no place to mothers-or fathers for that matterexcept to dramatize the tragic birth of a hero, as in the passage quoted at the beginning of this chapter, or to depict families in connection with the creation and perpetuation of a lineage.

For medieval saints, families were often seen as obstacles to spiritual salvation. The mystic Angela of Foligno, for example, considered the death of her entire family (including her mother) not only a deliverance from earthly ties but an answer to her prayers. ${ }^{23}$ In his Miroir de mariage the poet Eustache Deschamps lists more practical reasons for despising children: in infancy they create only noise, bad smells, trouble, and worry; they have to be fed and clothed; their lives are constantly at risk and should they manage to reach adulthood they could very well end up in prison. Positive attitudes toward childhood are hard to come by whether we look in clerical or secular writings. No wonder, then, that attitudes toward pregnancy were hardly more positive. Spiritually inferior and medically at great risk, the pregnant woman had little to look forward to. As Myra Leifer has pointed out, cultural and social pressures play an important role in pregnancy. ${ }^{24}$ These pressures were mostly negative in the Middle Ages and thus added to the burden any pregnancy, even the most desired, represented in a woman's life. From the 
many accounts of seventeenth- and eighteenth-century childbirth studied by Mireille Laget, a conclusion emerges that also holds true for the Middle Ages: "the woman appears traumatized by previous confinements or by the many stories she has heard." 25 The only people whom the pregnant medieval woman could turn to (except to her patron saint) and who could sympathize with her were other women.

At most births in the Middle Ages only women were present. An exception to this rule was royal birth. We know, for example, that in IIoI, at the birth of her first child, Queen Matilda, the wife of the English king Henry I, was assisted by two Italian physicians, a layman named Grimbald and the abbot of Abingdon, Faritius. ${ }^{26}$ Whether they assisted with the actual birth is not quite clear. They may just have been observers or in charge of the astrological speculations that accompanied every important birth. In any case, Matilda, unlike the unfortunate Blancheflor who did not survive the birth of her son Tristan, went on to have two more children but lost this first son while he was still an infant. Generally, however, birth belonged to the domain of daily life and was, if all went well, a nonmedical process. As indicated in the scene of the Les quinze joies, mothers, grandmothers, and neighbors would be present in addition to the midwife, who was a lay practitioner and often a person in possession of folk wisdom.

Certainly up to the fifteenth century being a midwife was not a profession; it was an activity, learned by apprenticeship, that involved as much psychological as physical assistance during and after the birth. 27

Childbirth had, of course, been treated in the classical corpus of medical texts, the Hippocratic and the Galenic. However, obstetrical material was not presented as a separate handbook, which could have been of use to midwives, for example. It was embedded in the theoretical discourse on conception, menstruation, and pregnancy, largely concerned with humoral theories, which governed every aspect of a human's well-being.

Several texts included speculations on what triggered the actual birth. The Hippocratics, for example, believed that, alarmed by the lack of food, the fetus would begin the birth process by its own initiative, ${ }^{28}$ while Galen introduced the concepts of the vis propultrix and the vis expultrix as the two forces that govern the two phases of birth. Other areas of concern were the positions of the fetus (only head first was considered natural) and how to remove a dead fetus (by violent shaking or with surgical instruments).

It was not until the appearance of Soranus of Ephesos's Gynecology 
(second century A.D.) that questions of female physiology, pregnancy, and birth were treated separately. Portions of his text survive only in later translations, that of Caelius Aurelianus (fifth century) and Moschion (sixth century). Soranus evidently had great confidence in the capacities of midwives, and he devotes twenty-eight chapters in his second book to pregnancy, childbirth, and the treatment and possible diseases of the newborn.

Soranus begins by describing the signs announcing the imminent birth and then specifies how a room should be prepared for a woman's labor: warm water, sponges, warm fomentations for the alleviation of pain, bandages (for swaddling), and "things to smell to revive the laboring woman" should be present. ${ }^{29} \mathrm{He}$ describes the birth stool in great detail, specifying the size of the cut-outs, the shape of the back and so on. ${ }^{30} \mathrm{His}$ instructions for the actual birth show great attention to the feelings of the woman in labor: the midwife should do nothing that may seem undignified or upsetting to the future mother. The positions indicated for the midwife and the helpers (one holding the woman from the back, the others at her sides) became a standard for obstetrical illustrations, as we will see in Chapter 2. The birth itself requires care and patience on the part of the midwife, who must beware of rupturing the perineum. The woman herself has to participate actively in the birth; Soranus makes it clear that mental attitudes play a role in this essentially physiological process. Once the child is born the "majority of women practising midwifery" approve of cutting the umbilical cord with glass, a reed, or other sharp objects but not with a knife. Here Soranus comments: "cutting with iron is deemed of ill omen. This is absolutely ridiculous, [for] crying itself is of ill omen, and yet it is with this that the child begins its life." Thus it is better to "be less superstitious and cut the navel cord with a knife." 31 Advice on cleansing, swaddling, and feeding the infant follows. Soranus is very explicit on how to select a wet nurse and what kind of regimen the nurse should follow in order to have healthy milk. ${ }^{32}$ Bathing (not too often so as not to soften the newborn) and massaging the newborn have the purpose of giving it the correct shape. For example, holding the child upside down will untangle the vertebrae. ${ }^{33}$ Soranus spends several pages on detailed instructions on how to mold the child, an indication of how "unfinished" and malleable the newborn was considered to be. Walking, weaning and teething, tonsillitis, itching, and flux of the bowels are the subjects that close book 2.

Difficult birth is treated in book 4 . The causes are divided into those 
relating to the mother and those relating to the infant. ${ }^{34} \mathrm{~A}$ large part of the text is devoted to detailed instructions (addressed to midwives) for version of the unborn in case of unnatural presentation. Although Soranus advises great delicacy and caution for any internal version, it is clear that his advice could rarely be applied competently: most midwives did not have the skills necessary for the maneuvers of a successful version; and since no hygienic precautions were taken, the intervention supposed to assure the mother's salvation often brought about her death.

The advice on version of the unborn reappears in later medical texts, notably in the De passionibus mulierum, now known as Cum auctor, a text for centuries wrongly attributed to so-called Trotula, or Trota, presumably a twelfth-century female physician from Salerno. ${ }^{35}$ In a Middle English version of this text no fewer than sixteen ways of unnatural presentation are described with "advice on how they are to be rectified." 36 While Soranus did not subscribe to some of the rather questionable methods proposed by some medical writers (for example, the violent shaking of pregnant women to induce the birth [often of a dead child]), even he called for desperate measures in the case of a permanently stalled birth: "If the fetus does not respond to manual traction, because of its size, or death, or impaction in any manner whatsoever, one must proceed to more forceful methods, those of extraction by hooks and embryotomy. For even if one loses the infant, it is still necessary to take care of the mother."37 Again, Soranus goes into great detail concerning the procedures of extraction by hooks and embryotomy where it finally made no difference whether the fetus was dead or still alive. The methods of fragmenting a fetus are described soberly: the first and foremost concern was to save the mother. For Soranus, Caesarean section does not exist as an option for terminating a protracted birth.

In the Trotula translated by Mason-Hohl, the only methods recommended for removing a dead fetus are induced sneezing, and if this does not work, "let the patient be placed in a linen cloth stretched by four men at the four corners with the patient's head somewhat elevated and she will give birth immediately, God favoring her." 38 The contrast with Soranus's text is striking. He devotes two extensive chapters to the removal of a dead (or impacted) fetus; the treatment in this popular medieval text is more than scanty.

Soranus's Gynecology contained much medical information and sensitive advice regarding childbirth. But although his text and its translations were transmitted to medieval Europe, it is not clear whether midwives 
could actually profit from these texts. Given the low rate of female literacy, at least up to the fifteenth century, it is likely that midwives, if they knew the texts at all, could have heard of them only indirectly. Probably knowledge of Soranus's tradition was largely confined to the learned sphere. ${ }^{39}$

The texts of Hippocrates, Galen, Avicenna, and others (as well as the many commentaries on them) became part of the university curriculum and were studied by physicians whose interest in practical medicine was limited and in obstetrics, almost nonexistent. ${ }^{40}$

But purely medical texts were not the only source for advice on childbirth. Bartholomeus Anglicus, the thirteenth-century encyclopedist, described the function of the midwife as follows: "The midwife is a woman who possesses the art of helping a woman in childbirth so that the birth goes easier and the infant is not endangered." 11 While Bartholomeus had dealt with theories of conception (based on Avicenna) in book 5 of his treatise and turned to diseases in book 7 , the remarks on midwives, wet nurses, and the care of the newborn infant are part of book 6, "De etatibus hominis" (Of the ages of man), which deals with a man's household and his family. Childbirth is thus presented in a nonmedical context.

As in many other parts of his book, Bartholomeus here relies heavily on ancient authorities while at the same time displaying a gift for the observation and description of contemporary daily life. Thus his remarks regarding the care of the newborn owe much to such writers as Constantinus Africanus, the famous eleventh-century translator of Arabic medical texts, but they probably also reflect what medieval midwives were expected to do. This included the cutting and tying up of the umbilical cord, and the washing of the infant, who was then dried in the sun or in front of a fire. Ointments were applied to the child's body and its palate and gums were rubbed with honey. Finally the baby was wrapped in soft cloths, often tightly wrapped swaddling clothes, as one can see in manuscript illuminations (for example, figs. I and 2). In accordance with Galenic theories, the newborn was seen as moist and soft and thus needed to be constricted in its movements. ${ }^{42}$ While today it is believed that swaddling actually comforts the newborn, Salvat suggests (without any direct evidence, however) that in the Middle Ages this practice may have been symbolic of the imprisonment by sin that the infant is subject to at the moment of its birth-not exactly a consoling thought for the new mother, who had just gone through the ordeal of labor. ${ }^{43}$ 


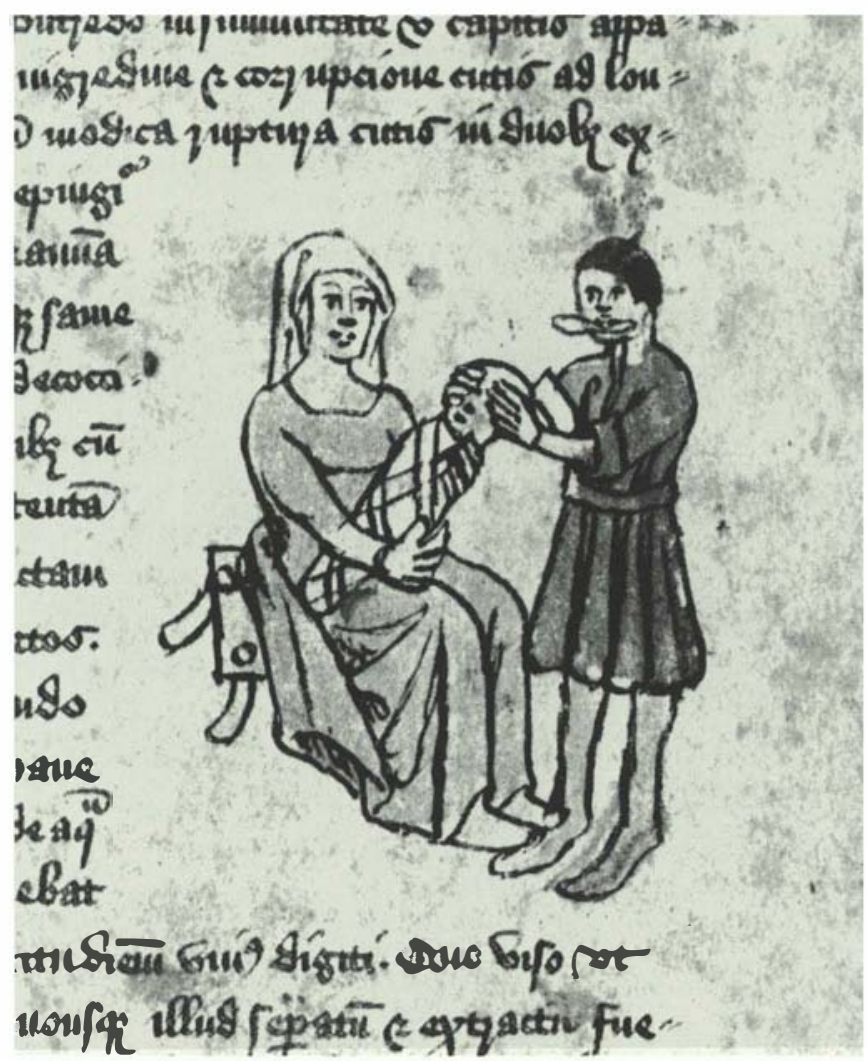

I. A head operation (John of Arderne, Speculum flebotomiae, University of Glasgow Library, MS Hunter i12, fol. 94r)

Bartholomeus's placing of childbirth in the chapter on the ages of man signals how childbirth was perceived in the Middle Ages. Despite the myriad medical writings on the subject, birth was still in the hands of midwives and consequently a nonmedicalized procedure, a part of daily life ruled by empiricism and not in the domain of the physician, a part that had not yet been embraced by what Foucault terms "le regard médical." 44 As for Caesarean sections, we can draw a preliminary conclusion at this point: while some of the ancient authorities mention surgical instruments in the context of embryotomy (the removal of a dead fetus in parts), none of them deals with surgical delivery as such.

The preceding paragraphs are, of course, not an exhaustive treatment of medieval birth or of the ideas on childbirth by medical writers. They 


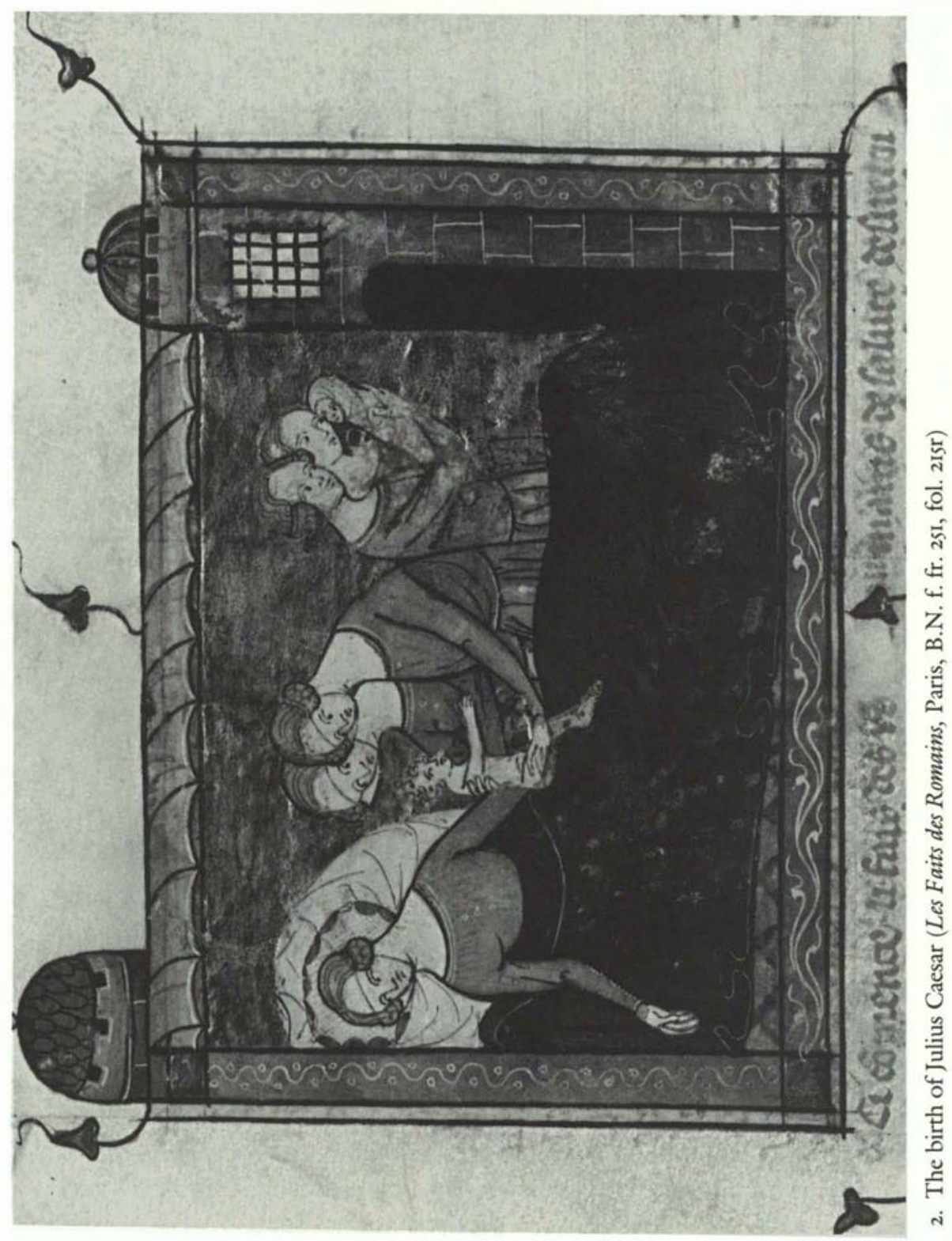


serve only to recreate, at least in part, the atmosphere, attitudes, and fears that must have attended any birth in the medieval and Renaissance period when the physician's involvement in childbirth was mostly theoretical and midwives had no effective means at their disposal to ease the pain of childbirth or to avoid complications during deliveries that often spelled the death of the mother. Frequent stillbirths and miscarriages and a high mortality rate of inf ants added to the stress experienced by medieval women during pregnancy. Caesarean section, representing as it does violence and mutilation, epitomizes the dangers of medieval and Renaissance childbirth. In the popular imagination it belonged to the realm of legends and miracles, but for midwives it was an eventuality they had to be prepared for.

The earliest testimonies of Caesarean birth do not mention midwives because there the operation appears mostly in a legal context or in works dealing with etymology. The actual performance of the operation was not of primary concern to the earliest witnesses, some of which we will now consider.

\section{Early Traditions of CaEsarean Birth}

The oldest presumed testimony of a Caesarean birth, from the second millennium B.C., appears in a cuneiform tablet from Mesopotamia, which contains a legal text dealing with the adoption of a small boy. ${ }^{45}$ The child is described as one "who was pulled out from the womb." Although, of course, pulling is not cutting, a Caesarean section may be meant; since the use of forceps for the delivery of a living child was unknown until the early modern period, it is unlikely that a normal birth would be referred to in such terms. ${ }^{46}$ In addition, "to pull the baby out" is exactly the term used to describe a Caesarean section in the marginal instructions to the illuminator in the manuscript Princeton Garrett 128 (fig. 3) ${ }^{47}$ Most likely, then, this phrase refers to a Caesarean section.

The first explicit mention of Caesarean birth goes back to about 715 B.C., when the lex regia was proclaimed by the Roman king Numa Pompilius. The law stated that it was unlawful to bury an undelivered woman before the child had been cut out. Whoever broke this law caused a living being to die together with the pregnant woman. ${ }^{48}$ The lex regia was transmitted by the sixth-century Byzantine emperor Justinian I through his Digesta, a compilation of legal texts. ${ }^{49}$ From the existence of 


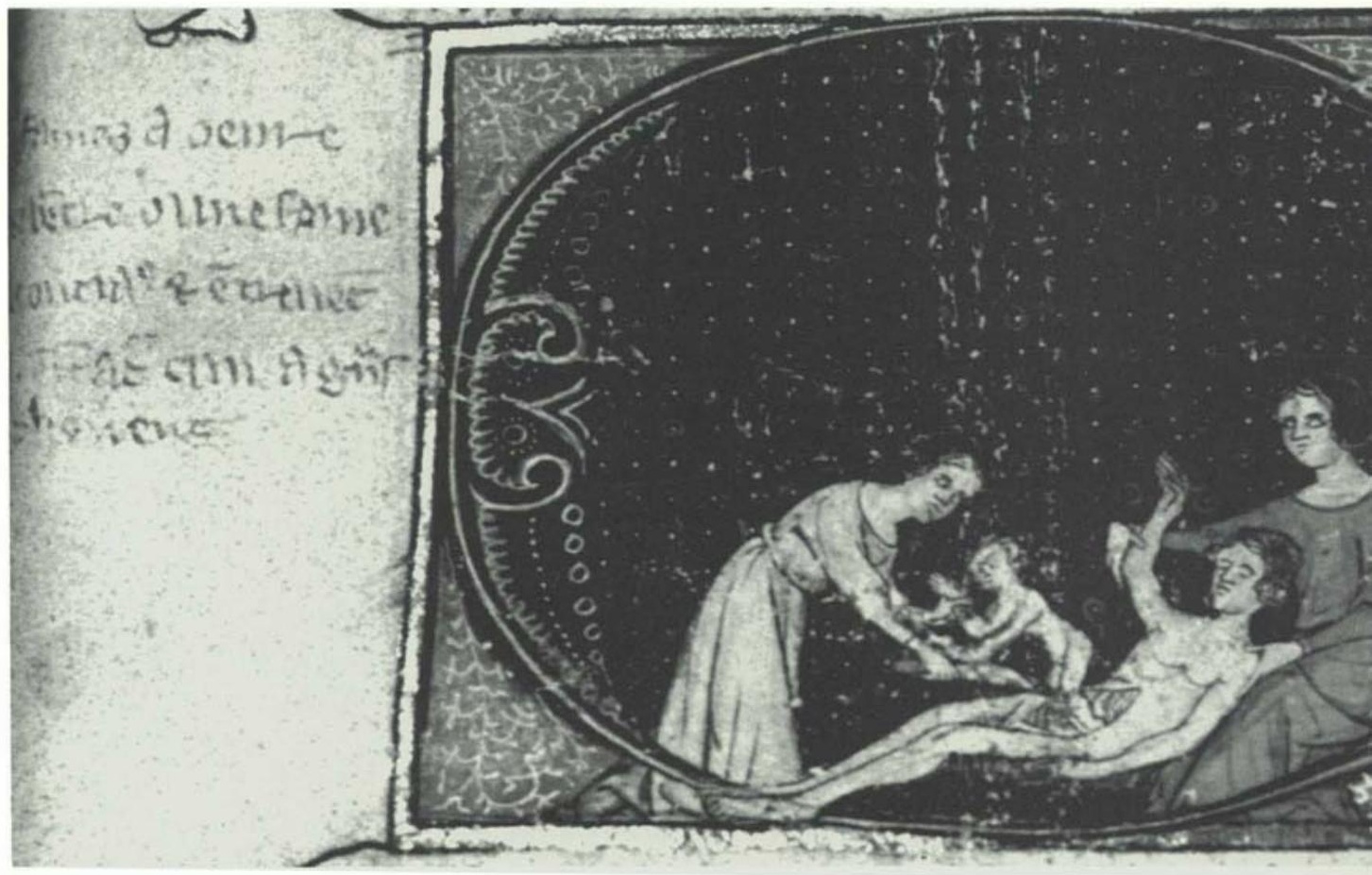

3. The birth of Julius Caesar (Les Faits des Romains, Princeton University Library, MS Garrett I28, fol. $144 \mathrm{r}$ )

this law one can conclude that Cacsarean sections were performed postmortem in order to save the child. Unfortunately neither the indication for a Caesarean nor possible techniques were mentioned.

Another early testimony can be found in the writings of the Indian doctor Sûsruta, who lived sometime between the fifth century B.C. and the second century A.D. In chapter 8 of his Nidânasthâna he urges a Caesarean in case the mother dies during birth and movements of the child can still be detected. The operation has to be done quickly, he adds, for a delay could cause the death of the child. ${ }^{50}$ Other Indian medical writers in the early Middle Ages repeat this advice.

Early Jewish culture also seems to have known of Caesarean birth. A passage from the Mishna, which contains texts from the third century B.C. to about the third century A.D., states that "in the case of twins, neither the first child which shall be brought into the world by the cut in the abdomen, nor the second can receive rights of primogeniture, either 
as regards the office of priest, or succession to property."51 Was a Caesarean ever practiced on living women in this early period? Jeffrey Boss is convinced that Caesareans with maternal survival were quite common in the Jewish tradition, but even he has to admit that "the mother's recovery after caesarean section is implicit rather than explicit in the relevant passages." 52 From the following passage in the Nidda, an appendix to the Talmud, it has often been concluded that Jewish culture knew and practiced this operation on living women: "It is not necessary for women to observe the days of purification, after removal of a child through the parieties of the abdomen." 53 The medieval commentator, physician, and author of medical texts Maimonides (II35-I204) advised that an incision should be made in the woman's side and that she should in this way be delivered of her child. ${ }^{54}$ It is not clear whether in this case the survival of the woman was assumed. The mention of the dispensation from purification would suggest that it was; but possibly this passage is of a purely theoretical nature, which would correspond to a tendency in Jewish commentaries to provide for even the most unlikely cases. For the time being, then, the question of maternal survival of Caesareans in the ancient Jewish world has to be left unresolved.

The next witness to Caesarean birth, Pliny the Elder (A.D. 23-79), makes much of the auspiciousness of Caesarean birth when he discusses the term caesones in his Natural History (7.9), but he supplies no medical information. (Still, his text is important for the history of the term "Caesarean section"; see Appendix.)

In Greek and Byzantine medical writings no mention is made of the operation. ${ }^{55}$ In the Islamic world, the tenth-century chronicler al-Bīrūnī mentioned the operation in the context of the birth of Julius Caesar: an illustration in a fourteenth-century manuscript of his Chronology of $A n$ cient Nations shows a group of bearded men surrounding an obviously dead woman just delivered by Caesarean. Peter Soucek suggests that this illustration was based on a medical handbook (although he does not say which one). ${ }^{56}$ Several Arabic writers indicated the possibility of surgical intervention during birth with instructions for midwives or surgeons, but they do not mention Caesarean section. ${ }^{57}$ From the indications supplied by Manfred Ullmann one can conclude that certain operations, such as the removal of a woman's bladder stones, were performed by midwives (or "chaste" surgeons) under the supervision of a physician. ${ }^{\mathbf{8}}$ Later, Western medical writers, such as François Rousset, likened the operation for bladder stones (in terms of surgical technique) to the 
Caesarean operation, but in the Arabic tradition there is unfortunately no evidence of such a parallel; it would give us some insight into whether and how the operation was performed.

How, then, did the Caesarean section become part of medicine and how does it fit into the medieval medical canon? And how did midwives eventually know of and learn about the operation?

We find no remarks on Caesarean sections performed post-mortem in the European tradition before the early fourteenth century. Since in this operation the mother's death was presupposed and the fetus's death almost certain, it is likely that the Caesarean section was initially not considered a medical procedure and consequently had no place in the canonical works of school medicine. If it was part of medicine at all, it belonged to the realm of surgery rather than obstetrics, although in its early stages the operation was performed mostly by midwives. There is no one explanation for the entry of Caesarean section into medical works; rather, the preconditions must be sought in many areas.

\section{SURgery, CaEsarean BirTh, AND \\ DISSECTION BEFORE I3OO}

Although a few Caesarean births are mentioned in various early medieval texts, the operation as a medical procedure is not known to appear in medical writings prior to Bernard of Gordon, a Montpellier physician, who mentions it in book 7 of his compendium Practica sive lilium medicinae (1305). I would suggest that a combination of factors led to the inclusion of the operation in learned treatises: the laicization of surgery; the increasingly explicit directions for Caesareans issued by various church councils; the new definitions of areas of professional competency regarding physicians and surgeons; and finally the performance of autopsies and dissections, which started in the thirteenth century.

In the early Middle Ages medicine was in the hands of the clergy. Both monks and nuns could act as physicians, and nuns could take over the office of midwife in the community to which the convent was attached. 59 Hildegard of Bingen is well-known as a woman belonging to a religious order who was knowledgeable about medicine and wrote several medical books. ${ }^{60}$ Often nuns had to act as physicians and surgeons out of sheer 
necessity, to staff hospices and hospitals, for example. Surgery at this time consisted mostly in bloodletting and the treatment of wounds. ${ }^{61}$

The laicization of surgery began in the twelfth century when the church forbade its clergy to perform procedures that involved the shedding of blood. At its origin this interdiction had nothing to do with the church's "abhorrence of blood." The first interdictions against the practice of medicine and law on the part of the clergy had different and more general motivations. Canon number 5 of the Council of Clermont in II3O, canon 6 of the Council of Rheims in II3I, and canon 9 of the Second Lateran Council in 1139 all state that "monks and canons regular are not to study jurisprudence and medicine for personal gain." 62 Thus monks and canons regular (that is, members of the regular clergy) were excluded from the practice of these two professions because through them they might fall into the sins of avarice and cupidity and forget their true vocation: to serve God and save souls. ${ }^{63}$ At the Council of Tours in II63, Pope Alexander III warned the clergy against entanglement in the affairs of this world.64 The canon "Ecclesia abhorret a sanguine" (The church abhors blood) often attributed to the Council of Tours is a literary fiction that proved surprisingly tenacious despite Charles H. Talbot's observation that the phrase "owes its existence to Quesnay, the uncritical historian of the Faculty of Surgeons at Paris, who in 1774, citing a passage from Pasquier's Recherches de la France ["et comme l'église n'abhorre rien tant que le sang"] translated it into Latin and put it into italics." 65 No earlier source for this sentence can be found.66 Originally, then, the practice of medicine was proscribed only as part of a dangerous involvement in worldly affairs, especially if it was practiced for gain and not out of compassion.

In 1215, at the Fourth Lateran Council, those members of the secular clergy who had taken major orders (subdeacons, deacons, and priests) were included in a new interdiction against the practice of that part of surgery that involved cutting and burning (phlebotomy and cauterization). Even if these interdictions were not always observed, as Ernest Wickersheimer has shown, they were nevertheless responsible for the laicization of surgery and for the beginning of the power struggle between different groups of professionals. ${ }^{67}$ We can now understand why the Caesarean operation, a medical procedure that consisted of "cutting" and that took place post-mortem, could not be part of clerical medicine and was initially left to midwives. 
The church prescribed Caesareans primarily for the sake of baptizing the newborn child. It seems that the Parisian archbishop Odon de Sully (II96-I208) was the first church official to recommend a Caesarean if there was a chance that the child was still alive after the death of the mother: "Mortuae in partu scindantur, si inf ans credatur vivere; tamen si bene constiterit de morte earum" (Those who have died in childbirth should be cut open when the child is believed to be still alive; however, it has to be well established that they are dead). ${ }^{68}$ The Council of Canterbury in 1236 stipulated that in case of the mother's death her body should be cut and the child extracted. The mother's mouth should be held open during this procedure. The same council urged women to confess themselves before they went into labor, and midwives were instructed to prepare water for a possible emergency baptism. ${ }^{69}$ Thus the midwife had to be prepared for the eventuality of a fatal outcome of any birth she attended. She had to make quick decisions, for the eternal salvation of the infant was at stake.

How complex and problematic these decisions were can be seen from a text composed at the Council of Trèves in I310: "Should a woman die during childbirth her body should be opened immediately and the child be baptized if it is still alive. If it is already dead it has to be buried outside of the cemetery. However, if one can assume that the child is already dead in its mother's body both of them should be buried in consecrated ground."70 This passage has often been cited in order to underline the importance of the baptism of newborns. But it also points up the dilemma that a medieval midwife could find herself in. The salvation of the child, both physically and spiritually, depended exclusively on her. A mistake in her judgment could lead to the burial of the child in unconsecrated ground. The risk of the infant's spiritual damnation could be greatly lessened, it seems, if the question of its physical survival is treated as secondary, that is, if the midwife "decides" that the child is already dead before a Caesarean can be attempted. That midwives were deeply concerned with the newborn's salvation can be seen from the many accusations leveled against them for secretly baptizing stillborn children and burying them in consecrated ground. 71

Another important decision confronted the midwife: should the mother ever be sacrificed for the sake of her child? Since baptism was of such paramount importance, the "hastened" death of the mother may have allowed the midwife to save an otherwise doomed child. Saint Thomas Aquinas in his teachings on baptism provides a clear answer to 
this question: “' Evil should not be done that good may come,' according to St. Paul [Rom. 3:8]. Therefore one should not kill the mother in order to baptize the child; if, however, the child be still alive in the womb after the mother has died, the mother should be opened in order to baptize the child." 72 This opinion is reiterated in the sixteenth century by Saint Charles Borromeus. ${ }^{73}$ Thus the choice indicated by Henry VIII, "Save the child by all means, for it is easier to get wives than children," was not the one recommended by such religious thinkers as Saint Thomas. ${ }^{74}$ In fact, in the English translation of the text attributed to Trotula midwives were openly advised to kill the child rather than to risk the life of the mother: "whan the woman is feble and the chyld may noght comyn out, then it is better that the chylde be slayne than the moder of the child also dye." 75 Of course, the church was against abortion, but it seems that at least in the context of Caesarean birth the question of a choice between the mother's or the child's life never arose.

The midwife, then, deemed competent and even urged to be familiar with the rituals of baptism, stood at the borderline between different groups who contended for the salvation of the patient: the clergy, now unable to intervene surgically, and the lay surgeons, whose areas of competency grew not only through the new restrictions of clerical medicine but also, as we will see, because of new requirements concerning autopsies and dissections.

One area that has some bearing on the question of Caesarean birth is the conflict that seems to have existed between clerical and lay physicians about who was to be present at a person's deathbed. Whereas in earlier councils, such as the Council of Canterbury (1236), the sick were urged to call first a "physician of souls" (canon 34), later councils, such as the Council of Ravenna (13II), had somewhat more faith in the "physician of bodies," who is given at least one chance at saving the patient before a "doctor of souls" has to be called in: "We alert all doctors that they are not allowed to return to the patient before they have assured themselves that he has called a doctor of souls and has taken care of his spiritual salvation."76 But after this first attempt, the hope for physical salvation had to give way to the hope for spiritual salvation. Thus science is given a chance, but faith has the last word.

It seems, then, that one of the results of the laicization of surgery was an increased presence of laymen at the moment of a person's death. A Caesarean, performed as it was post-mortem, could now interest surgeons. The operation began to move from the purely religious sphere 
(religious, at least as far as the motivation, that is, baptism, was concerned) to a medical one. Although male surgeons did not perform the operation at this point, it began to attract the attention of medical writers, such as Bernard of Gordon.

In the century preceding Bernard some shifting had occurred in the areas of competency assigned to physicians and surgeons. From a practical (not a theoretical) perspective the interests and the healing activities of university-trained physicians had been rather limited. They consisted largely in uroscopy, the taking of the pulse, the consultation of astrological charts, and the prescription of various herbal concoctions. Although in the early Middle Ages bloodletting, or phlebotomy, had been the task of the physician, in the later Middle Ages it and most other surgical interventions were left to surgeons and barbers who learned their trade through apprenticeship. ${ }^{77}$ Thus the practical activities of physicians were more restricted than they had been in earlier periods. Professional fields had to be redefined, a process that led to a split between physicians and surgeons.

In France, this split began in earnest after the emancipation of the Faculty of Medicine at the University of Paris in 1272, when new rules governing the issue of licenses went into effect. ${ }^{78}$ Some twenty years later the Italian surgeon Lanfranc of Milan (d. I3IS) came to Paris to teach among other subjects the surgical material then current at Bologna. He deplored the rivalry between surgeons and physicians and pointed out that a good practitioner should be well versed in surgery and medicine. ${ }^{79}$ Pouchelle suggests that Lanfranc's courses, given as they were at the Faculty of Medicine, may have caused physicians to fear even more for their cherished domain of school medicine. ${ }^{80} \mathrm{~A}$ surgeon was regarded as an intruder in the confines of the university of Paris; consequently, in the fourteenth century, Henri de Mondeville, although a surgeon of great fame, was forced to teach outside of the university. ${ }^{81}$ The surgeons, for their part, showed the same disdain toward the barbers that the universitytrained doctors displayed toward the surgeons. ${ }^{82}$ Thus those medical treatises which showed a strong interest in surgery-and which began to treat Caesarean sections-did not come from Paris but, rather, from places like Montpellier, where surgery formed part of the school curriculum.

The division between the different professional groups was of course not as radical as the various decrees to this effect would make it appear. 
There were always individuals who did not conform to the strict rules desired by university-trained doctors. In general, a great discrepancy existed between medical theory and practice, but some medical practitioners managed to bridge this gap through their writings. ${ }^{83}$ Even though close to 70 percent of French medical writings from the thirteenth to the fifteenth centuries were the work of university-trained physicians, two of the most interesting medical treatises of the fourteenth century were written by the surgeon-authors Henri de Mondeville and Guy de Chauliac (who were, however, among the last of their genre, as Pouchelle points out).$^{84}$

Because medical compendia like Bernard of Gordon's contained a number of surgical elements from preceding centuries, we should also consider, however briefly, the tradition of surgical writing before the fourteenth century. In the twelfth century, an important compilation of surgical texts (mostly based on classical sources), now known as the Bamberg Surgery, had been assembled in Salerno; it was soon supplanted by Roger of Frugardi's text on surgery, especially important to surgeons in Bologna and to Guillelmus de Congenis of Montpellier. ${ }^{85}$ Also in the twelfth century, Gerard of Cremona made available Arabic surgical treatises in Latin translations, which influenced the Italian surgeons Bruno da Longoburgo, Hugh of Lucca and his son Theodoric of Cervia, and William of Saliceto and his student Lanfranc of Milan.

Thus the thirteenth century produced a number of important surgical treatises that incorporated practical experience often gained on the battlefield. Lanfranc, for example, begins his treatise with extensive sections on different types of wounds and, with the exception of a few theoretical chapters, concentrates on the practices of bloodletting and cauterization and such matters as the treatment of cataracts, what to do about the swelling of limbs (apostemas), and the surgical removal of stones. The comprehensiveness of Lanfranc's treatise reminds us that surgery was, according to Dino del Garbo (a student of Taddeo Alderotti), one of the three important ways "of treating a sick body (the others were diet and medication.)"86 The surgical aspects of obstetrics, such as embryotomy, which were very prominent in the Arabic tradition, had no place in a treatise like Lanfranc's.

Surgical treatises (originating mostly in Italy) left their mark on thirteenth-century medical compilations, such as Gilbertus Anglicus's Compendium medicinae, which contains several quotations of Roger of Parma's Chirugia. ${ }^{87}$ The Compendium, based on Aristotelian principles 
and the ideas on the four humors, also features many recipes. Its subtitle (Nondum medicis sed cyrurgicis utilissimum, (Most useful not only for physicians but also for surgeons) underlines its usefulness for both professional groups. It begins with a treatise on fevers and then covers a large variety of diseases, beginning with those of the head and ending with diseases of the reproductive organs. Gilbertus concludes with remarks on such varied topics as leprosy and dog bites. In the tradition of medical compendia he deals with pregnancy and delivery, but it is interesting that he does not go into details of the surgical removal of a dead fetus, let alone Caesarean section. The only recommendations in this context are various fumigations and induced sneezing (fols. 306 and 307). The Compendium's structure provided the model for Bernard of Gordon's Lilium, but Gilbertus's scanty treatment of obstetrical and gynecological questions cannot be compared with Bernard's extensive chapters on these subjects. Bernard does appear, then, for some areas at least, as an innovator. Before turning to Bernard's text let us briefly look at one more important factor that conditioned the medical milieu of the early fourteenth century: the history of dissection, which began in the late thirteenth century.

The teaching of anatomy required dissections, but before the late thirteenth century only animals were dissected. The observations made during these procedures were then applied, with modifications of course, to humans. Many misconceptions regarding human anatomy were thus created and perpetuated. This is not to say that once human cadavers were dissected these misconceptions disappeared: observation did not necessarily supersede received book learning. ${ }^{88}$ Dissection was, rather, the "solemn illustration of the learning inherited from the ancients," especially Galen, whose texts were read as an accompaniment to the practical demonstration. ${ }^{89}$ But dissection did allow for some new insights. ${ }^{90}$ It also broke the taboo of opening up the human body.

In 1299 Pope Boniface VIII promulgated a bull that raised some questions on the admissibility of human dissection. It forbade the boiling of human cadavers in order to separate the flesh and the bones. Apparently this technique was used so that the bones of crusaders who died abroad could be repatriated and was seen by the pope as a violation of the integrity of the human body. ${ }^{91}$ It seems that the church never expressed a clear opinion on the subject of anatomical dissection. ${ }^{92}$ Thus the bull 
does not seem to prohibit dissection as such; its injunctions only preclude the study of skeletal anatomy.

It was toward the end of the thirteenth century that the first dissections were done in Bologna, an innovation "associated with the circle of Taddeo [Alderotti]" and the new requirements of academic medicine. ${ }^{93}$ Even before Mondino de Luizzi, the author of the influential Anatomia (1316/17), began to conduct regular dissections as part of the university curriculum, Taddeo alluded to a dissection, stating that he could not solve a certain problem because he had been unable to examine the anatomy of a pregnant woman. ${ }^{94}$ But, as Nancy Siraisi points out, it was only in response to the needs of a privileged and organized faculty of arts and sciences that regular dissections could take place. ${ }^{95}$

Dissections were conducted according to a certain ritual order, described by Guy de Chauliac in his Grande chirurgie (1363). Each successive stage was accompanied by a lecture: "the first on the digestive system, liver, and veins, ... the second on the heart and arterial system, the third on the brain and nervous system, and the fourth on the extremities."96 But dissections were not done frequently, even in Bologna. In France, regular dissections began to be performed in Montpellier in 1376 (despite a stipulation of 1340 that a dissection should take place every two years); the Faculty of Medicine in Paris waited until 1407 to perform its first dissection, which seems to have been more of an autopsy. ${ }^{97}$

In France, autopsies brought surgeons into contact with the judicial authorities as early as the beginning of the fourteenth century. The surgeon's reports are not very revealing, stating in one case that a certain butcher had indeed died from a fall into a well but without any visible wounds, or in another that a certain woman's head wound stemmed from an ax. ${ }^{98}$ But we have to appreciate the efforts made at the turn from the thirteenth to the fourteenth century to base judgments on evidence obtained through the surgeons' first-hand observation, as inadequate as their expertise may appear to us today.

Through dissections and autopsies, then, the taboo of opening the human body was broken. These developments most likely contributed to Bernard of Gordon's decision to include remarks on Caesarean section in his Lilium. His is the first known Western text dealing with the operation, and thus he is a privileged witness for the textual developments of Caesarean birth. Then, in the fifteenth century, when it seemed that Caesarean birth could be wrested away from the realm of death, newly 
confident surgeons began to describe how they themselves performed the operation. The trend of medical optimism culminated in François Rousset's writings in the late sixteenth century, only to be obliterated by the subsequent generation of surgeons in the seventeenth.

\section{The Textual Tradition of Caesarean Birth}

Bernard of Gordon most likely spent his whole life in southwestern France. He probably studied and certainly taught at Montpellier in the late thirteenth and early fourteenth centuries. ${ }^{99}$ The division between surgery and university medicine was not as pronounced in Montpellier as it was in Paris. Surgery was taught together with medicine and "practised by physicians."100 Practical experience was required for licensing. As Demaitre has shown, even though the manual operations were left to surgeons, the doctrina of surgery formed part of the university education of physicians. ${ }^{101}$ Arnold of Villanova, for example, accused his Parisian and northern colleagues of "too much absorption in book learning," a good indication that practical matters were of great importance in Montpellier. ${ }^{102}$ In this context it makes sense that the two earliest texts that give a place-however small-to postmortem Caesarean birth should originate in a milieu that valued surgery and boasted a number of firstrate physicians, such as Bernard and Guy de Chauliac, who, in addition to their university education, showed an interest or had received excellent training in surgery. Although their texts were steeped in the works of the ancients (Guy's citations of ancient and contemporary authors go into the thousands) and medical astrology was a favorite topic, there is some evidence of first-hand observation and practical thinking. Thus Bernard emended ancient authorities on the basis of "reason and experience."103 Like many other medical writers he frequently persuades his reader to accept certain findings as the results of personal experiments or deliberations while really relying on such works as Gilbertus Anglicus's Compendium medicinae. ${ }^{104}$ But there are instances where Bernard clearly acknowledges learning something about certain remedies per viam experimenti from old wives (a vetulis). ${ }^{105}$

Bernard conceived his work as one of medical practice and explicitly named "the humble" as his target audience, that is, novice physicians and, most likely, surgeons. ${ }^{106}$ Despite the importance accorded to surgery it 
was not a privileged method of treatment, for Bernard lists diet, regimen, medication, and surgery in descending order of preference. ${ }^{107} \mathrm{~A}$ surgeon, for him, was a restaurator to whom one turned as a last resort. Caesarean section, although not a procedure of "restoration," certainly is in line with the idea of a last resort.

It is in Bernard's Lilium, then, that we find the first known mention, in Western medicine, of Caesarean birth. ${ }^{108}$ At the end of book 7, chapter I5, "De regimine praegnantium," he cites Galen on the causes that initiate the birth: as a fruit falls from the tree so the fetus causes the rupture of the ligaments that hold it; they become fragile because of overextension and lack of nourishment. Immediately after these remarks, Bernard says that sometimes, even though the mother dies, the fetus may survive, at least for a certain time, through the air that still is in the mother's arteries. In that case, the mother's mouth should be opened and an incision should be made in her abdomen through which the child should be extracted. $\mathrm{He}$ also advises that the cervix be held open to assure the influx of air during the operation. The method is referred to as artificium, that is, an artificial means. Bernard does not given any clear indication of where the incision is supposed to be located. He closes his remarks with a reference to the birth of "the first of the Caesars." 109

Given Bernard's other references to advice gathered from "old wives," one can speculate whether he learned about the operation from them. On the other hand, Bernard's reference to the legend of the birth of the "first of the Caesars" shows a familiarity with the learned tradition of the etymology of Caesar's name. But Pliny, the likely source for Bernard's reference, does not mention any medical details of the operation. In the learned textual tradition of medicine, as we saw above, Caesarean section was not mentioned. Consequently, the knowledge of the operation most likely has another origin, probably hearsay combined with some theoretical thoughts based on what was known about surgery, pregnancy, childbirth, and female physiology at the time.

In book 7, chapter 16, Bernard goes on to describe a natural birth (head first after seven to eleven or more months [sic] of pregnancy) and what constitutes an unnatural birth: any presentation other than head first. He then lists the reasons for a protracted birth and the symptoms by which one can recognize whether the feuts is dead. The reasons for difficult labor are divided into intrinsic and extrinsic. Bernard thus follows tradition. Among the extrinsic are excessive heat or cold, an inept midwife, a premature birth, an existing scar, or constipation. ${ }^{110}$ Intrinsic reasons are 
a prepubescent conception and the consequent narrow birth canal; obesity; extreme fear and delicacy on the part of the mother; a too large, too delicate, or dead fetus; two heads, or twins; unnatural presentation; or a small or too dry uterus. If none of the above applies, the reason has to be sought in the secundines (placenta).

The signs by which a dead fetus is signaled are facial discoloration and fetid breath; pain and immobility in the abdomen, Bernard specifies, are good reasons for increased vigilance. Bernard's remarks about the midwife's tasks and qualities recall some details of Soranus's Gynecology, notably the long and slim fingers required of a midwife. She is the one to deal with difficult labor through baths and fomentations, unguents and manual dilation of the cervix. In the case of an obstructing scar, surgical instruments should be used to open it. ${ }^{111}$

In Bernard's Lilium, then, the textual environment of the operation is that of obstetrics, but in practice the operation belonged to surgery. In the work of Guy de Chauliac we find somewhat more explicit instructions regarding the performance of a Caesarean section. Guy was one of the greatest surgeons of his century; he was trained at Montpellier and Bologna, traveled widely in his profession, and finally, about 1348, at the time of the great plague, became surgeon to Pope Clement VI in Avignon. In 1359 he was named provost of the chapter of Saint-Just in Lyons. He was highly regarded by several popes and at the time of his death in 1368 had just been honored once more by Pope Urban V.

Guy deals with the postmortem Caesarean in chapter 7 of the sixth treatise of his Grande chirurgie. He first lists possible reasons for a difficult birth: wrong presentation of the fetus (the only natural one is head first) and multiple births (Avicenna mentions quintuplets, Guy informs his readers; Abulcasis, even ten children born at one time); but, he adds, since it is mostly women who occupy themselves with such things it is hardly worth spending too much time on these questions. However, one should tell midwives (obstetrices) that if the birth is difficult despite normal presentation, unguents should be used to soften the birth canal. The woman herself should help by pressing, by holding her breath, and by sneezing, which might be induced by pepper or other substances. Cyclamen tied to the thigh facilitates the birth (say the experts). To correct unnatural presentation Guy recommends version of the unborn through external manipulation, for example, raising the thighs of the woman. He does not mention internal version, as did Soranus and others, possibly because his confidence in the midwives' abilities is lim- 
ited. Should the child die before delivery the midwife must try to extract the child either by hand (anointed with unguents) or by induced sneezing. Medicines with abortive powers (for example, castor, myrrh, and others) are recommended. If nothing works, the child should be extracted by hooks "entier ou en pièces."

Should it happen that the woman dies and the child is still alive-and as the king's order forbids burial of a pregnant woman before the child is extracted-one should hold open the mouth and the uterus of the woman (as the women - that is, midwives and female attendants-desire it) and make an incision with a razor along the left side, since this side is freer than the right side because of the liver. Through insertion of the fingers the child can then be pulled out. ${ }^{112}$

These instructions, of a purely practical nature, combine much of what we saw in such texts as Soranus's Gynecology. Guy also revives some forgotten techniques. The extraction by mutilating hooks, for example, had not been mentioned in detail since the period of Arabic obstetrics. ${ }^{113}$ But he also displays anatomical knowledge (position of the liver), some legal wisdom, and familiarity with learned legends. Even though this obstetrical chapter constitutes only a minute part of Guy's gigantic work and even though he denigrates female practitioners, some real concern seems to come through in the passages just summarized. For the first time a surgical instrument is specified; for the first time instructions as to the position of the incision are given. ${ }^{114}$ These innovations may reflect a concern for the improvement of the operating techniques of lay persons, notably midwives. They may also mark a step on the way to the medicalization of obstetrics and reflect the growing interest of male surgeons in this exclusively female domain.

It is only a few decades later that we encounter the first surgeon who in his writings lays claim to having performed a Caesarean and an embryotomy (after a Caesarean?) himself. Piero d'Argellata (d. I423), a professor at Bologna and the author of Chirurgia, writes about the extraction of the fetus in chapter 7 of book 5, treatise 19 . He follows Guy de Chauliac in many of his obstetrical remarks and also recommends the postmortem Caesarean: "One should hold open the mother's mouth as well as the uterus so that air can enter and the child can come out. The woman should be opened with a razor along the left side of the abdomen. . . . Some time ago I prudently made the incision along the linea alba up to the breast bone. Neither the intestine nor the child was touched and in this way I extracted the child". ${ }^{115}$ It is also possible to extract a dead child 
in this manner: the "perforation" is then held open by hooking the fingers along the incision, and the child is pulled out. Piero says, "Ego aliquando feci" ( $I$ once made) and "extraxi" ( $I$ extracted), clearly indicating that he performed the operation himself and did not relegate it to a midwife.

This innovative male presence is a fifteenth-century phenomenon. Giovanni Michele Savonarola (d. I466), who wrote a gynecological treatise in Italian, also recommends expert medical (that is, male) help when the future mother is a domina magna, or a wealthy woman. He limits these male consultations ("for poor people the doctor does not labor much"), ${ }^{116}$ but his recommendation nevertheless lets us discern the trend toward male participation in obstetrical procedures-a trend that was undoubtedly arrested by one obstacle, concisely expressed by Savonarola: generally, obstetrics was not one of the more lucrative branches of medicine.

Alessandro Benedetti (1450-I525) also recommended a postmortem Caesarean in chapter is ("De obstetricis officio") of his De re medica. Benedetti was a surgeon and anatomist from Bologna who, despite his reliance on the ancient authorities, managed to make some new discoveries, such as the vaginal glands later named after Bertholin. ${ }^{117}$ That it is again a surgeon who mentions the Caesarean is worthy of note.

In Germany, the situation was somewhat different. Midwifery there was subjected to official control in the form of statutes, usually issued by city councils, about a century earlier than in France (mid-fifteenth century versus about I560). One of these statutes, dating from about I480, comes from southern Germany and describes in great detail how a Caesarean should be performed. This text is unusually explicit:

Many mothers ask, when they feel that they are dying, to liberate the child by an incision. In that case, the skillful midwife has to open up one side, but not the right one; for in men the heart is located on the left side, but in women on the right side. She shall start cutting in the lower part of the belly around the pubic bone, about the width of one hand. With her oiled hand she must carefully move aside the entrails. The sick woman shall lie on her back with her head tilted back so that she can reach the uterus. After the opening of the uterus the woman should be tilted to one side, as the midwives know well. The child should be freed from the fetal membranes. But the woman, if she still seems to be alive, should be turned again on her back. The wound should be closed with three or four ligatures by means of a needle and a silk or other thread. On top of this should be placed a plaster 
made from three eggs and some fabric of strong hemp to which one may add, when available, some Armenian clay (bolus armenicus). The plaster should be tied onto the wound. The woman receives a sip of the best wine. Should she survive and regain consciousness, give her a drink made of the roots of salsify and of mountain albanum sautéed in wine. And the woman will recover with God's help. ${ }^{118}$

These instructions are clearly addressed to midwives and seem to assume a fair chance of the woman's survival. In reality, however, this chance was minimal, given the danger of infection.

One of the most important German texts of this period, Eucharius Roesslin's I513 Der Swangern Frawen md Hebammen Rosegarten (The pregnant women's and midwives' rose garden), is essentially a compilation of ancient texts on obstetrics. It starts right off with remarks on fetal positions and practical advice to midwives. Nevertheless, the identity of its addressees is ambiguous; they could be either male readers or female midwives. Still, the passage on Caesarean birth at the end of chapter 9 seems to be meant specifically for his (presumably male) reader. For whereas other instructions are prefaced by "the midwife should," in the passage on Caesareans Roesslin says, "You should" (soltu = sollst $d u) .{ }^{119}$ In any case, Roesslin's passages on the Caesarean section are an exact translation of Guy de Chauliac: he specifies the position of the incision (on the left, since on the right side is the liver); the instrument: a Schermesser (razor); the necessity to hold open the mother's mouth (also the uterus and the vagina [in an addition to Chauliac]); the removal of the child by hand; the reference to Julius Caesar's birth. Compared with the midwifery text just cited the instructions here are very scanty and of limited practical value. And yet, Roesslin makes an effort to get away from the even more useless type of natural history exemplified by the pseudo-Albertus Magnus's Secreta mulierum, which repeated ancient lore on astrology, conception, embryology, obstetrics, and the nature of women and thus was really an encyclopedia of what passed then as natural philosophy rather than of medicine.

One of the characteristics of texts preceding Roesslin was that they did not treat obstetrics as a separate discipline. It was seen either as part of surgery or in the wider framework of female physiology. Because Roesslin addressed himself in the vernacular specifically to midwives (through the probable intermediary of a literate male surgeon), he has always been hailed as the teacher of midwives in Europe. His attitude toward midwives was on the whole more positive and trusting than that of Guy de 
Chauliac, as can be seen through a minute change in the German text. Where Guy treats the holding open of the mouth (in reality a useless procedure) as a concession to the attending women, Roesslin sees the midwives' experience in a positive light when he says: "as women usually know well" (als die frawen gewonlich wol wissen). The German version of the Secreta mulierum, which antedates Roesslin by about sixty years, had contributed to the perpetuation of this idea in its short passage on Casearean section: "the mother's mouth should be held open with a little piece of wood and the fruit should be cut out of her body." 120 In any case, Roesslin tries to put some value on traditional beliefs of midwifery.

Despite some observations on present-day practices (notably on the birth stools common in Germany and France, in chapter 4) Roesslin's Rosegarten, like most medieval medical treatises, was steeped in preceding textual traditions rather than first-hand experience. But things began to change with the next generation of surgeon-authors, especially in France.

\section{FranÇOIS ROUSSET AND THE CONTROVERSY OVER CaEsareans ON Living Women}

The group around Ambroise Paré, one of the greatest surgeons of the sixteenth century, was responsible for a new approach - and a new rhetoric-in obstetrical writings. Most of his writings rely heavily on the ancients, but occasionally personal experience surfaces, if not always explicitly.

Parés theoretical objections to Caesareans on living women seem to have been based on the unfortunate experiences of his pupil and colleague Jacques Guillemeau, who performed several fatal Caesareans under his supervision. ${ }^{121}$ In his writings Paré does not mention any personal experience when he discusses postmortem Caesarean section. ${ }^{122}$ He especially insists on the speed with which such an operation has to be performed, since the child will have no way to breathe after the mother's death. He rejects the ideas that opening the mother's mouth and vagina could enable the child to breathe. ${ }^{123}$ The most important paragraph of this chapter is the last, in which he gives his reasons for rejecting Caesareans on living women:

I am surprised that there are people who claim to have seen women who, in order to be delivered of their children, had their abdomens cut open, not 
only once but several times. This seems impossible to me, since, in order to extract the child, a large incision has to be made in the muscles of the epigastrum and also in the uterus, which is so imbued with blood that a fatal hemorrhage would be the result. In addition, once the wound closes the scar would prevent the uterus from ever dilating again. . . I will never advise this procedure, which involves such great danger and offers no hope. ${ }^{124}$

It was this type of objection that Rousset addressed in the preface to his famous treatise, Traitté nouveau de l'bystérotomotokie, ou enfantement Caesarien (I58I). As a consequence of Rousset's work a bitter controversy erupted about the advisability of Caesareans on living women. ${ }^{125}$ In the I590s Rousset became the target of vitriolic attacks by Jacques Marchant and of somewhat more temperate attacks by Guillemeau. What was it in Rousset's treatise that aroused such strong passions and strong language?

The subtitle of Rousset's work indicates the revolutionary nature of his remarks: Extraction de l'enfant par incision latérale du ventre, et matrice de la femme grosse ne pouvant autrement accoucher. Et ce sans preiudicier à la vie de l'un, ny de l'autre; ny empescher la foecondité maternelle par après (The extraction of the child through a lateral incision of the abdomen and uterus of a pregnant woman who cannot otherwise give birth. And that without endangering the life of the one or the other and without preventing subsequent maternal fertility). The claim made in the last part of this subtitle went against all accepted medical wisdom of the time. Rousset is aware of this - and especially Paré's objections - when, in the part "Au Lecteur," he makes a reference to some "amiable disputes" he had with Paré over the birth, which he (Rousset) baptized "enfantement Caesarien." Nevertheless, in the first edition of Rousset's work Paré's approving signature can be found right next to that of the dean of the Faculty of Medicine, a testimony to an at least ambiguous attitude on Parés part toward the feasibility of a successful Caesarean. ${ }^{126}$ About a century later, François Mauriceau explained Paré's ambiguity on that subject by saying that this was "because he will not have posterity know that he was able to consent to so great a cruelty."127

Some of the ideological underpinnings of Rousset's thought are evident in the "Sonnet de l'autheur au lecteur chirurgien" (Sonnet of the author for the reader-surgeon) at the beginning of the treatise. Here he equates a difficult birth with the Gordian knot. Just as Alexander undid the knot with his sword ("au Couteau"), so the courageous surgeon should undo the "knot" of childbirth with his knife. The reward will not be all of Asia, as it was for Alexander, but the happiness of having given 
life to mothers and children ("et eux de toy tiendront la vie"). How radical and heroic the operation was for Rousset could not be better expressed than in the image of Alexander cutting through the Gordian knot. I believe that Rousset's texts can be read as a cry of protest against the general impression that male participation in obstetrics always involved death. Or, as Wilson puts it, "the task of the midwife was to deliver a living child, the task of the male practitioner a dead one."128

Rousset was aware of the novelty of his ideas. "Something unheard of, never written about, hardly credible to those who see it" is how he describes his subject in the prefatory epistle. Here he also justifies his using French instead of Latin by dedicating it to the poor women who must otherwise die without help and to surgeons whose Latin may not be excellent. He explains that a more ample treatise in Latin is to follow. ${ }^{129}$ Remarkably, the Latin translation by Caspar Bauhin was much more successful and saw many more editions than Rousset's French text. His intended audience clearly did not buy his treatise; he found his real audience among the learned physicians and those surgeons whose Latin was "excellent."

The text begins with a definition of a Caesarean (extraction of a childeither alive or dead - through the side of the mother by incision of the epigastrum and the uterus) and a refusal to speak of postmortem Caesareans (known already to the ancients). Rousset also explains the name of the operation by a reference to the "first of the Caesars who was Scipio Africanus," supposedly born this way. Thus Rousset does not subscribe to the legend of Julius Caesar's birth by Caesarean but, by creating the medical term, nevertheless kept this erroneous idea alive, since most people are aware only of the term and not of Rousset's explanation.

Rousset then lists the indications for a Caesarean section: if the child is too large or malformed or dead (in that case it may too bloated to be extracted by natural means); in the case of twins or of problematic presentation. Other indications concern the mother: if, through reasons of extreme youth or old age, she is too narrow or "hard," that is, not elastic enough. ${ }^{130}$

In the next section Rousset takes on the age-old tension between theory and practice as well as between the representatives of school medicine and those of rural practice. Since none of the ancients has written on the subject of Caesareans, learned doctors and surgeons give no credit to the practice, although operations of this kind have been and are being performed by rural barbers, if very rarely. Therefore-and here Rousset defines his rhetorical method-three means will be used to persuade the 
skeptics: experience (through case histories); pertinent reasons (through discussion of medical points); sufficient authority (discussion of possible analogies, wounds of a character similar to a Caesarean incision that have indeed been dealt with by the ancient authorities). ${ }^{131}$

As a preface to his case histories, Rousset describes his method of gathering evidence. He basically relies on the testimonies of "gens fidèles" (trustworthy people) and of "personnages non suspects."132 In other words, Rousset never performed the operation himself and was not even present at most of the cases he describes.

The first case concerns a woman named Anne Godart who gave birth by Caesarean six times in a row. At the seventh birth she died because her surgeon, Nicolas Guillet, had died some time before and no other surgeon was willing to perform the operation. In the second case, Rousset wanted to go and see the woman, who had delivered three times by Caesarean, but she died of the plague before he could get his first-hand testimony. The next two cases all concern multiple successful Caesareans, news of which was transmitted to Rousset by letter. Now a break occurs in the narrative. The next section is headed "Histoires oculaires" (Eyewitness stories). Rousset addresses the "ami lecteur" and defends himself against accusations of being inept, boring, and too concerned with particulars. The only way to get to the truth of matters, he says, lies in just such particulars. The next two stories involve Rousset directly. In the first, he examined a woman with a ventral hernia who explained that the long scar on her left side was the trace of a successful Caesarean performed seven years earlier by an old barber of her village. Rousset had intended to contact this barber but was, "through the difficulty of the times," unable to find the piece of paper on which he had written his name. Rousset's wish to "gather from him practical details gained from experience" remained unfulfilled. In the next case, Rousset actually witnessed the performance of the operation that he himself had advised for a woman in prolonged labor. Since the experienced surgeon Ambroise le Noir could not be found, a young barber ("le premier trouvé") performed the operation. Here we learn the exact date (Easter 1556) and the way the incision was made: on the right side about one finger down from the navel. The barber was so skillful that little blood was shed, and he managed to pull out the living child and the afterbirth. He then closed the wound with five stitches (he did not suture the uterus) and after forty days' bed rest the woman was well again. She later gave birth to a daughter naturally. ${ }^{133}$

The next cases concern the excision of dead fetuses. Here Rousset 
accuses several midwives who through their incompetence "broke up" a poor woman in such a way that, despite the successful removal of the fetus, she was ill for seven months. Similar remarks appear in the story of one Jeanne Michel, who was tormented by midwives without any result until, in the tenth month of pregnancy, she was finally delivered of a dead fetus. ${ }^{134}$

One thought is paramount in Rousset's writings: he wants to overcome the resistance to the operation on the part of medical practitioners. He encourages surgeons, such as Adam Aubry, not to waste time through cowardly reflections but to go ahead with a Caesarean as quickly as possible. ${ }^{135}$

Of the 228 pages of Rousset's treatise only 17 are devoted to case histories of successful Caesareans. One of the most dramatic stories of a successful Caesarean is not in Rousset's work proper but in the appendix to Bauhin's Latin translation of Rousset. It is that of Jacob Nufer, a Swiss pig gelder who, in the year I500, delivered his wife surgically after she had been in labor for several days. Great drama accompanied this operation, for Nufer first had to get the permission of the authorities, and courageous midwives had to be found (only two out of the thirteen he approached finally decided to assist this determined man). With a single deep cut he opened the uterus ("as if operating on a pig") and extracted the child at the first try. He then sewed up his wife in the same manner he used for his animals, and it was only then that the eleven timid midwives were allowed back into the room. The following year his wife supposedly gave birth to twins (without a Caesarean). Should this story be true it would indeed be remarkable. It is unlikely that Nufer sutured the uterus. In fact, Rousset specifies in several stories that surgeons did not suture the uterus. ${ }^{136}$ Some historians have doubted that Nufer performed a Caesarean at all and assert that his wife's pregnancy must have been extrauterine. Two factors argue against this, however, according to Pietro Gall: the mother's extended labor and the good health of the child. ${ }^{137}$ In the absence of asepsis and anaesthetics in this period the mother's survival in this as in all of Rousset's stories must be seen as a fortunate accident.

The second and third parts of Rousset's treatise contain an operating manual (where, for example, he compares a Caesarean with the operation to remove bladder stones), while the fourth part speaks of the dangerous alternatives to a Caesarean in complications such as a retained and putrid fetus, abcesses of the uterus or the hypogastrium (through extrauterine pregnancies). His point here is that in every case an extraction by incision 
poses the smallest risk. Here again, Rousset uses numerous case histories, some of them in letters addressed to him, to buttress his arguments. He def ends himself repeatedly against allegations that his cases took place far away; to counter certain attacks he tells some stories that happened closer to Paris, as if this geographical proximity guaranteed the stories' veracity. ${ }^{138}$ Part 5 deals with experimental surgery (specifically the removal of the uterus in animals without any adverse effect), and part 6 explains that a Caesarean does not impede a woman's fertility.

Rousset's treatise is remarkable for its passionate tone and polemical stance. Acerbic remarks on the incompetency of midwives stand side by side with accusations against the cowardly passivity of many surgeons. Radical innovation and active intervention in childbirth are his tenets, which did not endear him to the established medical community. According to Young, Rousset's work "was a masterpiece, and he appears to be the first writer who had the courage to advise the performance of the operation upon a living woman." Pundel also lauds Rousset for his theoretical descriptions (many of which are still true today), although he doubts that under sixteenth-century conditions Rousset's recommendations could have ensured the success of the operation. ${ }^{139}$

But apparently it was exactly the courage praised by Young that made Rousset the target of a series of more and more vicious attacks by his colleagues, especially Jacques Marchant. ${ }^{140}$ Jacques Marchant's first Declamatio (2) was directed against Rousset's Dialogus of 1590 (I), in which the latter refuted all the accusations that had been leveled against his treatise of I58I. Written as an imaginary dialogue between two characters named Sozometer and Catagelastes, the Dialogus begins with an opposition of darkness and light, the light representing, of course, more enlightened medical views. Sozometer insists on the novelty of what he (Rousset) had written about Caesarean section and supports his remarks by some more case histories. These examples, he says, have been unjustly attacked. Interesting in the context of the question of possible audiences for medical treatises is the defense of writing in French: "Gallus ego, ad Gallos, de Gallis, Gallica scripsi” (I am French, I have written for Frenchmen, about Frenchmen, in French), says Sozometer. And why should he not write in French, since all the ancients wrote in their own languages? In addition, as usefulness is one of the aims of a medical treatise, the French language lends itself better to this aim. (The Dialogus itself, of course, being a polemical tract and not a practical handbook, is in Latin.) Sozometer admits that the ancients did not speak of Caesarean section, 
but in general terms, he adds, they advocated that "what could be done, should be done." His counterattack against famous and mendacious doctors who condemned his innovations and his use of case histories culminates in the enumeration of the empty trappings these professionals care for, namely "tituli, gemmae, toga, pilea, otia privatae, nomine dicta gradus" (titles, jewels, clothes, hats, leisure time, and to be addressed by their degrees). Caesareans are not popular with this kind of doctor because a successful operation brings very little praise and its failure great blame. ${ }^{141}$ The Dialogus ends with an attempt to counter Paré's accusations of Rousset's being an impostor who should revoke his writings. In a long series of classical examples one point is illustrated again and again: that one has to show initiative and courage for innovative procedures even at the risk of being maligned and misunderstood.

Clearly, the Dialogus failed to convince Jacques Marchant. Marchant first refutes Rousset's observations on the analogy between the Caesarean operation and procedures that can safely be done on animals (the fifth part of Rousset's treatise) and then goes on to use the same arguments as Paré to demonstrate the impossibility of a successful Caesarean: the large wound in the epigastric muscles, the loss of blood from the uterus and its fatal consequences. Therefore, he says, this dangerous and desperate procedure should never be undertaken. After a whole list of examples of unsuccessful Caesareans recounted by various witnesses, Marchant addresses himself directly to Rousset: "Cannot the above examples bring you to revoke your sententia? No," he answers for himself, "you are too obstinate."142

Marchant also raises the fundamental question of "natural" versus "unnatural" childbirth by appealing to the concepts of nature, tradition, and practice. How can a surgeon show so much temerity, he asks, to plunge his hands into the side of a pregnant woman, when nature indicates a natural way of exit? In addition, of the learned ancients not one mentioned Casearean section in his writings. As for practice, Marchant points out that women are very patient in childbirth and that therefore it would be better to wait for a natural birth rather than to rush into a desperate and doomed operation. Against male involvement in obstetrics he puts forward that women are so much more experienced in the "mysteries of Lucina."143

The rhetoric of this part of Marchant's texts is still rather moderate. So is that of Guillemeau's letter to Rousset inserted in the first Declamatio. "We are not categorically against innovations," he claims, "but only 
against those that are horrible. But as to your small and inept collection of writings - I shall be silent on that topic." Guillemeau seems to have checked up on some of Rousset's eyewitnesses and have found them to be lying. To dramatize his points Guillemeau draws on his own experience of several failures in attempting Caesareans on living women, "done according to your specifications under monsieur Paré.” The moving descriptions of the women's deaths culminate in an ardent plea against the operation as envisaged by Rousset. ${ }^{144}$

It is in Declamatio III that Marchant's attack against Rousset becomes vicious. "Absurda, nugatoria, incredibilis" are the adjectives he uses to describe Rousset's so-called eyewitness stories. "How easy it is to hallucinate," he exclaims, "and thus to become the source of all errors. And this is what you have become, the creator of this plague which is sweeping Europe. You are nothing but a fraud." "Your beloved Caesar [that is, Caesarean section] now lies extinct in Europe," Marchant claims, undoubtedly alluding to the success his (Marchant's) writings had in dissuading surgeons from the operation. "And," he adds triumphantly, "to name this operation Caesarean section, was a disservice to your hero. You should have named it after the cruel Tarquinius who delighted in the blood and death of women." And Marchant goes on to write an imaginary inscription for Caesar's tomb that begins, "What lies here? Caesarean birth." There follows the death sentence for the operation, which is called "puer infoelix" (unfortunate boy). ${ }^{145}$

In Carmen, the poem that follows Declamatio III, Marchant reiterates his condemnation: "Caesarean birth is not reasonable and certainly not a remedy but rather a dangerous procedure which belongs to the 'ars carnificum.'"146 Against such an accumulation of passionate attacks Rousset could, in his final Responsio (7), do little more than repeat what he had said previously in his original treatise and the Dialogus.

During this heated exchange of views on the feasibility of Caesarean sections on living women an Italian doctor named Scipione Mercurio returned from a long trip to France and started to describe his experiences in his Commare o raccoglitrice. ${ }^{147}$ As early as $157 \mathrm{I}$ and 1572 learned doctors told him that in cases where the fetus was too large one could help pregnant women by an incision that could be made either in the right or the left side. No danger existed for the mother or child. "This," Mercurio admits, "did not seem impossible to me." Having never seen such an operation, Mercurio sought out a surgeon near Toulouse who went with him to see two women who had had Caesareans. One of them told 
Mercurio that she became pregnant again after the Caesarean and that this birth presented no problems. But, as for most of Rousset's cases, Mercurio saw the scars only after the fact. Nevertheless, he became an advocate of Caesareans on living women (but only if they were strong), especially after reading Rousset. Like Rousset, he asserts that "this remedy (the Caesarean operation) does not belong in the realm of midwif ery but into that of the doctor or learned surgeon," but only if he is "experienced, courageous, prudent and, above all, has a thorough knowledge of anatomy."148

Mercurio developed his own theories concerning the Caesarean birth and, like Rousset, he used the analogy of operations for bladder stones to demonstrate its feasibility. Today Mercurio is probably best known as the first medical writer to name a narrow pelvis as an indication for a Caesarean and as the only surgeon who took Rousset's side in his own writings.

From a modern perspective, both sides in the quarrel about Caesareans on living women were right and wrong. In Young's judgment, Rousset's treatise was a masterpiece; Newell, as well, while claiming that most of the pregnancies observed by Rousset must have been extrauterine, concedes that "this treatise had one great merit in that it brought the operation to the attention of the medical profession and suggested the possibility of its performance on living women." 149 But, of course, given the conditions prevailing in the practice of medicine at Rousset's time, his advice was close to foolhardy, and Marchant's passionate rejection of Rousset seems justified. Nevertheless, Rousset made a case for medical innovation and initiative that was to bear its fruits many centuries later.

In this chapter I have placed the Caesarean section in the context of pregnancy and birth in the medieval period as well as in the context of medical writings on these subjects. Outside of the medical literature and some religious writings, little attention was given to these profoundly female functions. Birth was a little-valued and dangerous process in which the Caesarean operation represented the extreme, that is fatal, outcome.

The most important factor for the emergence of Caesarean birth as a medical procedure was the laicization of surgery, which prompted a new consciousness of professional competency on the part of the medical and surgical professions. The performance of dissections made possible new views about opening up the human body. The close alliance of theory 
and practice in Montpellier, and especially Bernard of Gordon's interest in matters conveyed to him by "old wives" and in artificia (more practiceoriented than that of his predecessors), led him to include the operation in his Lilium. Before the fourteenth century, Caesarean birth had been recommended purely in a religious context: midwives were urged to perform the operation in order to baptize the newborn.

The controversy about whether to perform a Caesarean on a living woman illustrated a surge of medical optimism-albeit limited to a few individuals, especially François Rousset-in the late sixteenth century that was quickly checked a few decades later. From a theoretical and ideological perspective, Rousset and Marchant provided us with discussions on concepts of nature, tradition, and practice that illuminate important currents in Renaissance medicine.

Most important, male surgeons, motivated by scientific, professional, and probably also by financial interests, began to perform Caesarean sections around 1400 . Thus it was through Caesarean birth that they entered the field of obstetrics, and they did so much earlier than previously thought.

The close connection between birth and death that existed in the Middle Ages is most dramatically highlighted in Caesarean birth; let us now turn to the images that show us women-both mothers and midwives - confronted by the ultimate threat in which two lives hang in the balance: death in childbirth. 